
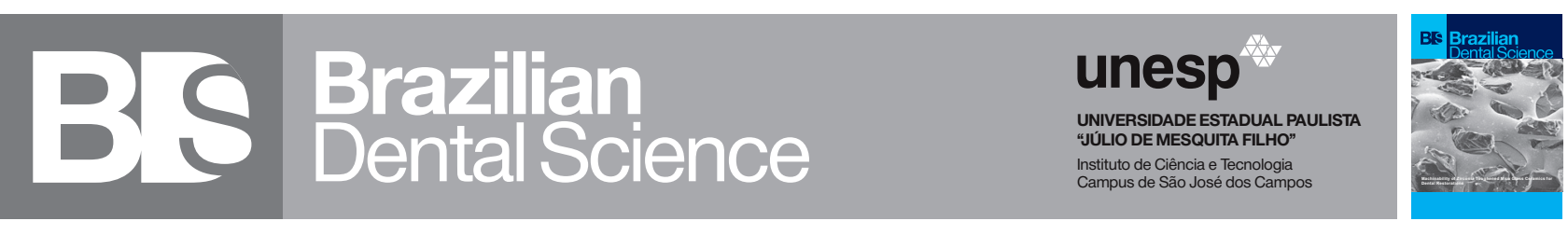

\title{
Effect of ultrasonic vibration on microshear bond strength of flowable composite to enamel
}

\author{
Efeito de microcisalhamento com vibração ultrassônica na resistência de união de compósito fluido ao esmalte \\ Mahtab EBRAHIMI NEZHAD ${ }^{1}$, Dana JAFARPOUR ${ }^{2}$, Mahdi Gholamrezaei SARAVI ${ }^{3}$ \\ 1 - School of Dentistry, Shiraz University of Medical Sciences, Shiraz, Iran. \\ 2 - Biomaterials Research Center, School of Dentistry, Shiraz University of Medical Sciences, Shiraz, Iran. \\ 3 - Department of Restorative Dentistry, School of Dentistry, Mazandaran University of Medical Sciences, Sari, Iran.
}

\section{ABSTRACT}

Objective: The present study aimed to assess the influence of vibration effect on microshear bond strength ( $\mu \mathrm{SBS}$ ) of flowable composite to enamel. Material and Methods: Sixty non-carious extracted human premolar teeth were collected and randomly divided into six groups $(n=10)$ after being trimmed to produce a smooth flat surface: Flowable composites [Wave (SDI), Wave HV (SDI) and Grandioflow (Voco)] were used as bonding agents without or with vibration using an ultrasonic scaler (Mini Piezon, EMS, Switzerland). Composite resin, with an internal diameter of $0.7 \mathrm{~mm}$ and height of $1 \mathrm{~mm}$, was cured on the substrate. The specimens' $\mu$ SBS was tested by a microtensile tester (Bisco, USA) at a crosshead speed of $0.5 \mathrm{~mm} / \mathrm{min}$. The bond strength values were analyzed using one-way ANOVA and post hoc Tukey test ( $\mathrm{p}<$ 0.05). Results: Vibration did not lead to any significant difference in the $\mu \mathrm{SBS}$ values of Wave, Wave $\mathrm{HV}$, and Grandio Flow $\mu \mathrm{SBS}$ values $(\mathrm{P}=0.690, \quad \mathrm{P}=1.000$ and $\mathrm{P}=0.947$, respectively). No significant difference was found between flowable composites in terms of micro shear bond strength to enamel ( $\mathrm{p}>$ 0.05). Conclusions: The application of ultrasonic vibration might not be advantageous in terms of improving the shear bond strength of flowable composites to enamel.

\section{KEYWORDS}

Bond strength; Enamel; Flowable composite; Ultrasonic; Vibration.

\section{RESUMO}

Objetivo: Este estudo teve como objetivo avaliar a influência de microcisalhamento com efeito de vibração na resistência de união ( $\mu \mathrm{SBS}$ ) de compósito fluido ao esmalte. Material e Métodos: Sessenta dentes pré-molares humanos extraídos não cariados foram coletados e divididos aleatoriamente em seis grupos ( $\mathrm{n}=10)$ após serem desgastados para produzir uma superfície lisa e plana: Compósitos fluidos [Wave (SDI), Wave HV (SDI) e Grandioflow (Voco)] foram usados como agentes adesivos sem e com vibração através de um aparelho ultrassônico (Mini Piezon, EMS, Switzerland). Uma resina composta, com diâmetro interno de $0,7 \mathrm{~mm}$ e peso de $1 \mathrm{~mm}$, foi polimerizada no substrato. Os espécimes de $\mu \mathrm{SBS}$ foram submetidos a teste de microtração (Bisco, USA) em uma velocidade de $0.5 \mathrm{~mm} / \mathrm{min}$. Os valores de resistência adesiva foram analisados através de testes de ANOVA a um critério e de Tukey post hoc ( $\mathrm{p}<0.05)$. Resultados: A vibração não levou a nenhuma diferença significativa nos valores de $\mu$ SBS entre Wave, Wave HV, e Grandio Flow ( $\mathrm{P}=0.690, \mathrm{P}=1.000$ e $\mathrm{P}=0.947$, respectivamente). Não foi encontrada nenhuma diferença significativa entre os compósitos fluidos quanto à resistência de união ao esmalte quando sob microcisalhamento ( $\mathrm{p}>$ 0.05). Conclusões: A aplicação de vibração ultrassônica pode não ser vantajosa para uma melhora na resistência adesiva de compósitos fluidos ao esmalte frente a cisalhamento.

\section{PALAVRAS-CHAVE}

Resistência adesiva; Esmalte; Compósito fluido; Ultrassônico; Vibração. 


\section{INTRODUCTION}

A lthough significant improvements have been established in adhesive dentistry, researchers still struggle to improve the strength and durability of dental adhesives. In this regard, the addition of fillers to adhesives has been attempted as a method of augmentation [1]. It has been reported that increasing the amount of filler in adhesives offer numerous benefits such as a reduction in the polymeric matrix with a subsequent increase in the Modulus of Elasticity, an increase in the bond strength, improved mechanical properties of the bonded layer, increased resistance to crack propagation, reduced polymerization shrinkage and lower coefficient of thermal expansion [2-6].

Although previous studies showed that flowable composites resins with high filler content-can be used instead of unfilled resins in bonding composite to enamel and porcelain substrates [7,8], higher filler content in the adhesives can increase their viscosity with a consequent decrease in their permeability which, thereby, can lead to diminished bond strength $[9,10]$.

Investigating prior literature on the effect of agitation has shown that it can increase the movement of monomers, leading to greater penetration of monomers into irregularities and outward flow of solvent $[11,12]$. Moreover, agitation in self-etch systems produces a uniform etching, escalates the effects of acidic monomers on the tooth surface, and disperses the etching products in hybrid layer resulting in superior adhesive distribution, and finally, improved effect on smear layer [13]. According to earlier findings, rubbing, brushing, and ultrasonic agitation may lead to enhanced bond strength $[11,13,14]$. Previously, studies were also conducted to evaluate the effect of vibration on the permeability of the adhesive to the pores created by etching and verified its positive effect on the improvement of bonding agent quality $[12,15]$.
Vibration is achieved through ultrasonic devices with high frequency. The use of high frequency ultrasonic with vibration and cavitation mechanisms improves the wetting property and chemically activates bonding agents. The ultrasonic might result in adhesives flow into empty tubular spaces and ease of resin tag formation. Some studies reported that the use of ultrasonic influences the thixotropic properties of the cements and results in reduced composite resin viscosity, causing better wetting properties and greater fit to dental structure. Radiation pressure is another consequence of ultrasonic which works as mild continuous pressure in the direction of wave propagation on the surface. Furthermore, superior solvent elimination is achievable via ultrasonic which may lead to better resin dissemination $[11,16]$.

To the authors' best knowledge, there is no published data on the effect of vibration on highly viscose adhesives with high filler content. Therefore, this study aimed to assess the influence of vibration effect on microshear bond strength of various flowable composites with varying filler content to enamel. The null hypothesis tested was that there is no difference in microshear bond strength among the flowable materials evaluated.

\section{MATERIAL AND METHODS}

A description of materials used in this study is presented in Table I. The study was approved by the local ethics committee (\#1716). A total of 60 extracted premolars extracted for orthodontic reasons (from July 2019 to Aug 2019) were collected for this study. Written informed consent was obtained from the parents or guardians at the time of tooth extraction. The parents were informed about the purpose of the study, privacy preservation, and data anonymity. After visual inspection and by means of a caries indicator (Seek ${ }^{\circledR}$, Ultradent ,USA), teeth with any sign of decay, defect, or discoloration were excluded from the study. The teeth were first disinfected in $0.5 \%$ chloramine-T for one week 
at $4{ }^{\circ} \mathrm{C}$, and then, stored in saline till used. Then the buccal surfaces of the specimens were trimmed using a 600-grit silicon carbide paper (Struers A/S, Copenhagen, Denmark) to produce a smooth flat surface.

Table I - Description of materials

\begin{tabular}{ccc}
\hline Manufacturer & Containing & Material \\
\hline Wave & $\begin{array}{c}37 \% \text { wt. multifunctional } \\
\text { methacrylic ester } \\
\end{array}$ & $\begin{array}{c}\text { SDI } \\
\text { (Australia) }\end{array}$ \\
& $\begin{array}{c}34 \% \text { wt. multifunctional } \\
\text { methacrylic ester }\end{array}$ & SDI \\
Wave HV & $66 \%$ inorganic filler & (Australia) \\
& Bis-GMA, UDMA, TEGDMA & Voco \\
Grandioflow & $80 \%$ inorganic filler & (Germany)
\end{tabular}

The prepared surfaces $\left(4 \mathrm{~mm}^{2}\right)$ of the specimens were first etched for $20 \mathrm{~s}$ with phosphoric acid (Etch-Rite, Pulpdent, Watertown, USA), rinsed with water for $15 \mathrm{~s}$, and gently air-dried for $15 \mathrm{~s}$. The specimens were then randomly divided into six groups according to the bonding technique $(\mathrm{n}=10)$.

In groups I, II, and III, Wave (SDI, Australia), Wave HV (SDI, Australia), and Grandioflow (Voco, Germany) flowable composites were respectively applied on the surface for $5 \mathrm{~s}$ using a microbrush and then dispersed by gently applying a weak air stream for $10 \mathrm{~s}$. The specimens were then light-cured for $20 \mathrm{~s}$.

In groups IV, V, and VI, Wave, Wave HV, and Grandioflow flowable composites were respectively applied on the surface for $5 \mathrm{~s}$ using a microbrush. Then vibration was applied on teeth for $10 \mathrm{~s}$ using an ultrasonic scaler (Mini Piezon ,EMS, Switzerland) with an intensity of 5 and a frequency of $28 \mathrm{kHz}$. This study employed the middle frequency of the device. Afterwards, the specimens were gently air-dried for $10 \mathrm{~s}$ and light-cured for $20 \mathrm{~s}$.
Clear plastic molds (Tygon tubes) with an internal diameter of $0.7 \mathrm{~mm}$ and height of $1 \mathrm{~mm}$ were placed on the surfaces, filled with composite (Ice, SDI, Australia; Shade $\mathrm{A}_{2}$ ), and light-cured for $40 \mathrm{~s}$. The excess material was removed, using a scalpel (Juya, Iran). After one $\mathrm{h}$, Tygon tubes were removed from the specimens using the scalpel. The specimens were placed in incubator maintained at $37{ }^{\circ} \mathrm{C}$ for $24 \mathrm{~h}$.

The specimens were light-cured using an LED unit (Radii plus, SDI, Australia) with an intensity of $1200 \mathrm{~mW} / \mathrm{cm}^{2}$. The light was irradiated directly at a distance of $1 \mathrm{~mm}$ from the surface. The irradiance level of the light was monitored with IL1700 radiometer (International Light Technologies; Newburyport, Massachusetts, USA) to ensure an output of $1200 \mathrm{~mW} / \mathrm{cm}^{2}$.

The specimens were stressed until failure in a microtensile tester (Bisco, USA) at a crosshead speed of $0.5 \mathrm{~mm} / \mathrm{min}$ and load cell of $10 \mathrm{kgf}$. The micro-shear bond strength of each specimen was calculated and expressed in MPa.

\section{Data Analysis}

Data were statistically analyzed using SPSS software (version 22, SPSS Inc., IL, USA). One-way ANOVA and post hoc Tukey test was used for analysis and $p<0.05$ was considered statistically significant.

\section{RESULTS}

Mean and standard deviation of $\mu$ SBS values are presented in Table II. As revealed in the table, there was no significant difference between the $\mu$ SBS of Wave specimens with or without vibration $(\mathrm{p}=0.690)$. Moreover, vibration did not lead to any significant difference in neither of Wave $\mathrm{H}$ and Grandio Flow $\mu$ SBS values $(\mathrm{p}=1.000$ and $\mathrm{p}=0.947$, respectively). 
Table II - Mean \pm SD microshear bond strength values of the experimental groups (MPa).

\begin{tabular}{|c|c|c|c|}
\hline \multirow{2}{*}{ Groups } & \multicolumn{2}{|c|}{$\mu \mathrm{SBS}(\mathrm{MPa})$} & \multirow{2}{*}{ P value } \\
\hline & w/o vibration & With vibration & \\
\hline Group I(Wave) & $17.24 \pm 3.15$ & $20.76 \pm 5.99$ & 0.690 \\
\hline Group II (Wave H) & $21.90 \pm 4.61$ & $22.56 \pm 1.45$ & 1.000 \\
\hline Group III (Grandio Flow) & $22.78 \pm 1.79$ & $24.90 \pm 4.20$ & 0.947 \\
\hline
\end{tabular}

\section{DISCUSSION}

One of the methods of improving the bond strength to tooth structures is to enhance the mechanical properties of the adhesive layer and adding fillers are among the approaches to achieve this goal [3]. Previous research has shown that high filler-containing flowable composites with sufficient flow and wetting can substitute filler-free resins without any bonding agents and provide acceptable bonding [17]. Another advantage of the flowable composites over the bonding agents is the variety of colors available in these composites, which includes all the colors of the Vita color selection guide [18]. In addition, due to the presence of filler, the flowable composites have less polymerization shrinkage than bondings [17].

However, an increase in the filler content of the adhesives can lead to an increase in its viscosity and concentration and a decrease in the amount of penetration into the irregularities caused by acid etching, resulting in a decrease in bond strength $[9,19]$. Investigating the effect of vibration has been previously conducted with an aim to increase the penetration of adhesive into the pores created by acid etching. So far its positive effect on bonding quality has been confirmed $[12,14,15]$.

In this study, the micro-shear bond strength of composite to enamel was investigated using different types of flowable composites with different filler content with and without vibration application. The micro-shear bond strength test has advantages such as ease of application and validity for bond strength testing
[20]; therefore, it was implemented in this study for the measurement of bond strength.

Previously published data confirm the similarity of agitation applied with various techniques such as ultrasonic, brush agitation, scrubbing and other types of agitation when used on self-etch adhesives [21,22]. In the present study, to assess the effect of agitation, ultrasonic vibration was employed. According to a previous study [14], the use of ultrasonic instruments for more than $15 \mathrm{~s}$ with power higher than 5 was not advantageous. In the present study, power 5 was implemented for 10 $s$ based on a pilot study, however, it did not also show any significant improvement in the bond strength.

The effect of vibration using ultrasonic device on the bond strength to enamel has not been widely investigated and most of the research has been carried out on dentin and especially self-etch adhesives. In the present study, however, the application of vibration was assessed on enamel bond strength. As our findings revealed, the mean shear strength of the enamel increased in all three groups although the increase was not significant. Despite the fact that the vibration did not significantly improve the bond strength, a tendency to increased micro-shear bond strength was observed and perhaps a higher sample size could have offered a better interpretation.

While numerous studies with controversial results have been conducted on the effect of vibration on dentin bond strength, the number of studies evaluating vibration effect on bond strength to enamel is limited and therefore comparison with previous literature was not feasible. Only previously, Lee et al. [23] reported an increased bond strength and greater number of resin tags after using ultrasonic. According to Lee et al. [23], the shear bond strength values in vibration groups were greater than those of non-vibration group in enamel. The authors concluded that vibration resulted in 
more mineral loss in enamel and longer resin tag and greater number of lateral branches in dentin under SEM examination.

The findings of the present study revealed that although the values for microshear bond strength were slightly higher in Grandioflow compared to Wave HV and Wave, the difference was not statistically significant. However, in a study by Najafi et al. [2], Grandioflow showed significantly higher bond strength compared to the other tested flowable materials. A possible explanation for the discrepancy between our findings on Grandioflow and those of Najafi et al. can be the fact that while we investigated the immediate bond strength, they assessed the bond strength following aging, and thus, the significantly greater bond strength value of Grandioflow compared to Wave HV and Wave in their study could be due to 9 months of aging implemented in their study.

In the present study, no significant difference was found between Wave and Wave $\mathrm{HV}$ in terms of bond strength to enamel. Najafi et al. [2] also found no statistically significant difference for Wave HV and Wave MV shear bond strengths in their study. The researchers concluded that the use of flowable composite instead of bonding is generally acceptable for composite and enamel bonds, confirming the results of previous similar studies [17,24]. D'Attilio et al. [17], who declared a comparable bond strength for flowable composites, reported a mean bond strength value of $24 \mathrm{MPa}$ for their tested composite which was similar to the values of the evaluated flowable composites in the present study.

Uysal et al. [25], who compared the bond strength of brackets to enamel using three different flowable composites, showed that the use of a flowable composite results in a decreased bond strength compared to conventional orthodontic adhesives. The higher viscosity of the composite and inadequate exposure below metal brackets might have resulted in low bond strength in the study.
Several studies have shown that besides resin penetrations, the bond strength is dependent on several factors including the mechanical properties of the resin [26, 27]. According to a study by Swift et al. [28], the bond strength to etched dentin relied on the substitution of hydroxyapatites with resin. Hence, considering these findings, it can be concluded that adhesion is a multifactorial issue and further studies are still required to investigate the methods to achieve and maximize the optimum bond strength.

One of the limitations of this study was the limited sample size. Moreover, given the controversial findings on vibration effects in previous studies and regarding the variations in the vibration time and frequency, the time for vibration application may have not been enough and therefore there is an urge to assess different vibration times and parameters to substantiate the data achieved in this research. Furthermore, for a better interpretation of the effect of flowable composites bond strength to enamel, considering a control group consisting of only adhesive system is further recommended.

\section{CONCLUSION}

Within the limitations of the present study, it can be concluded that the application of ultrasonic vibration might not be advantageous in terms of improving the shear bond strength of flowable composites to enamel.

\section{Funding}

The research did not recieve any specific funding.

\section{Conflict of interest}

None

\section{Acknowledgment}

\section{None}

\section{Ethical committee}

The ethical committee number of the process: (\#1716) 


\section{REFERENCES}

1. Blunck U. Effect of one-year waterstorage on the effectiveness of dentin adhesives in Class V composite resin restorations. J Dent Res. 2002;81:A-139.

2. Najafi-Abrandabadi A, Najafi-Abrandabadi S, Ghasemi A, Kotick PG. Microshear bond strength of composite resins to enamel and porcelain substrates utilizing unfilled versus filled resins. Dent Res J. 2014;11(6):636.

3. Wilson N,Dunne S, Gainsford I.Current materials and techniques for direct restorations in posterior teeth: Part2: resin composite systems. IntDentJ. 1997;47(4):185-93.

4. Unterbrink GL, Liebenberg WH. Flowable resin composites as" filled adhesives": literature review and clinical recommendations. Quintessence Int. 1999;30(4).

5. Inoue M, Finger W, Mueller M. Effect of filler content of restorative resins on retentive strength to acid-conditioned enamel. Am J Dent 1994;7(3):161-6.

6. LiY,Swartz ML, Phillips RW, Moore BK, Roberts TA. Materials Science Effect of Filler Content and Size on Properties of Composites. JDent Res. 1985;64(12):1396-403

7. Appeldoorn RE, Wilwerding TM, Barkmeier WW. Bond strength of composite resin to porcelain with newer generation porcelain repair systems. JProsthet Dent 1993;70(1):6-11.

8. Lacy AM, LaLuzJ, Watanabe LG, Dellinges M. Effect of porcelain surface treatment on the bond to composite. J Prosthet Dent 1988;60(3):288-91.

9. Nunes MF, SwiftEJ, Perdigao J. Effects of adhesive composition on microtensile bond strength to human dentin. Am J Dent. 2001;14(6):340-3.

10. Frankenberger R,Lopes M,Perdigão J, Ambrose WW, Rosa BT. The use of flowable composites as filled adhesives. Dent Mater.2002;18(3):227-38.

11. do Amaral RC, Stanislawczuk R, Zander-Grande C, Michel MD, Reis A, Loguercio AD. Active application improves the bonding performance of selfetch adhesives to dentin. J Dent. 2009;37(1):82-90.

12. Mena-Serrano A, Costa T,Patzlaff RT, Loguercio AD, Reis A. Effect of sonic application mode on the resin-dentin bond strength and dentin permeability of self-etching systems. J Adhes Dent 2014;16(5):435-40.

13. Bagis B, Turkaslan S, Vallittu PK, Lassila LV. Effect of high frequency ultrasonic agitation on the bond strength of self-etching adhesives. J Adhes Dent. 2009;11(5).
14. Fagundesa TC, Barata TJE, BrescianiE, Cefaly DFG, Carvalho CAR, Navarro MFL. Influence of ultrasonic setting on tensile bond strength of glass-ionomer cements to dentin. J Adhes Dent. 2006;8(6).

15. Cantoro A, GoracciC,Coniglio I, Magni E,Polimeni A, Ferrari M. Influence of ultrasound application on inlays luting with self-adhesive resin cements. Clin Oral Investig. 2011;15(5):617-23.

16. Jang J-H, Jeon B-K,Mo SY,Park M,Choi D, Choi K-K, et al. Effect of various agitation methods on adhesive layer formation of HEMA-free universal dentin adhesive. Dent Mater J. 2018.

17. D'Attilio M, Traini T,Di lorio D, Varvara G, Festa F, Tecco S. Shear bond strength, bond failure, and scanning electron microscopy analysis of a new flowable composite for orthodontic use. Angle Orthod. 2005;75(3):410-5.

18. Albers HF. Tooth-colored restoratives: principles and techniques:PMPH-USA; 2002.

19. Buonocore M, Wileman W, Brudevold F.A report on a resin composition capable of bonding to human dentin surfaces. J Dent. 1956;35(6):846-51.

20. Shimada Y, Tomimatsu N, Suzuki T,Uzzaman M, Burrow M, Tagami J. Shear bond strength of tooth-colored indirect restorations bonded to coronal and cervical enamel. Oper Dent. 2005;30(4):468.

21. Finger $\mathrm{W}$, Tani C. Effect of application mode on bonding performance of selfetching adhesives. Am JDent. 2005;18(1):41-4.

22. Miyazaki M,Platt J, Onose H, Moore B. Influence of dentin primer application methods on dentin bond strength. Oper Dent. 1996;21:167-72.

23. Lee B-E, Jang K-T, Lee S-H, Kim C-C, Hahn S-H. Effect of Ultrasonic Vibration on Enamel and Dentin Bond Strength and Resin Infiltration in All-in-One Adhesive systems. J Korean Acad Pediatr Dent. 2004;31(1):66-78.

24. Ryou D-B,Park H-S, Kim K-H, Kwon T-Y.Use of flowable composites for orthodontic bracket bonding. Angle Orthod. 2008;78(6):1105-9.

25. Uysal T,SariZ,Demir A. Are the flowable composites suitable for orthodontic bracket bonding? Angle Orthod. 2004;74(5):697-702

26. Fanning D. Effect of a filled adhesive on bond strength in three dentinal bonding systems. Gen Dent. 1995;43:256-62.

27. Amory C,Yvon J. Shear bond strength of a light-cured resin composite vs. dentin characteristics. Dent Mater. 1994;10(3):203-9.

28. Swift E, Wilder A, May K, Waddell S. Shear bond strengths of one-bottle dentin adhesives using multiple applications. Oper Dent. 1997;22:194-9.

\section{Dana Jafarpour}

(Corresponding address)

Research Associate, DDS, Biomaterials Research Center, School of Dentistry, Shiraz University of Medical Sciences, Shiraz, Iran.

Email: djafarpur@yahoo.com

Date submitted: 2020 May 29

Accept submission: 2020 Jul 31 